\title{
Beyond the glass ceiling: Does gender matter?
}

\author{
Renée Adams \\ University of Queensland and ECGI \\ Patricia Funk \\ Universitat Pompeu Fabra
}

First Draft: January, 2009

This version: September, 2009

\begin{abstract}
The representation of women in top corporate officer positions is steadily increasing. However, little is known about the impact this will have. A large literature documents that women are different from men in their choices and in their preferences, but most of this literature relies on samples of college students or workers at lower levels in the corporate hierarchy. If women must be like men to break the glass ceiling, we might expect gender differences to disappear among top executives. In contrast, using a large survey of all directors of publicly-traded corporations in Sweden, we show that female and male directors differ systematically in their core values and risk attitudes. While certain population gender differences disappear at the director level, others do not. Consistent with the findings for the Swedish population, female directors are more benevolent and universally concerned, but less power-oriented than men. However, they are less traditional and security-oriented than their male counterparts. Furthermore, female directors are slightly more risk-loving than male directors. This suggests that having a women on the board need not lead to more risk-averse decision-making.

Keywords: Female Directors, Directors, Gender, Boards, Values, Risk

JEL codes: J16; G30

*Correspondence: Renee Adams, UQ Business School, University of Queensland \& ECGI. Email: r.adams@business.uq.edu.au; Patricia Funk, Department of Economics, Universitat Pompeu Fabra, Email: Patricia.Funk@upf.edu.

We would like to thank Antonio Ciccone, Christian Hilber, Dominic Rohner, Carmit Segal and various participants at Universitat Pompeu Fabra, the 5th International Meeting on Experimental and Behavioral Economics (IMEBE), the 2009 annual meeting of the European Economic Association, the 2nd Women on Boards conference and the 2008 meeting of the Swiss Economists Abroad for useful comments.
\end{abstract}




\section{Introduction}

In the light of recent corporate scandals and the ongoing financial crisis, the question has been raised whether things would be different if more women ran corporate America (Huffington, 2003). One benefit of diversity is that people with different backgrounds may have different viewpoints. As Kirk and Gwin (2009) argue, these may be particularly valuable in difficult economic times. Kristof (2009) points out that financial firms are particularly male-dominated and suggests that this may have contributed to the recent poor performance of banks. Harriet Harman, UK Labour party's number 2 , has gone so far as to blame the financial crisis on the male domination in banks (Morris, 2009). Consistent with the arguments that firms with more gender-diverse boards can perform better is new evidence in Adams and Ferreira (2008) that more gender diverse boards appear to be tougher monitors. For example, female directors have better attendance behavior at board meetings and tend to sit on more monitoring-related committees than male directors.

An important question for understanding the effect of increased female participation in corporate leadership is whether such differences in behavior are due to fundamental differences between men and women or due to the fact that women are in the minority. For example, female directors may behave differently because they are less connected to old-boys' networks and thus have more independence of thought. However, as their representation increases, they may build their own networks and/or get better integrated into existing networks and act less independently. On the other hand, if women and men are intrinsically different, then the presence of women may have long-term effects on corporate decision-making.

Much of the research on gender points to fundamental differences between men and women

(see Marini, 1990; Croson \& Gneezy, 2008). For example, gender gaps have been documented for risk attitudes (Eckel \& Grossman, 2008; Sapienza, Zingales \& Maestripieri, 2009), desired exposure to competition (Niederle \& Vesterlund, 2007), and altruistic behavior (Andreoni \& Vesterlund, 
2001). The studies suggest that women are generally more risk averse, less keen on being exposed to competition, and more altruistic when altruism is expensive. In the field of psychology, survey evidence documents gender differences in core values (see Schwartz \& Rubel, 2005) that are robust across cultures.

However, most of these studies focus on students, workers or the general population, thus it is unclear whether we should expect women at the top of the corporate ladder to be any different from men. In fact, there are several reasons why we might expect gender differences to vanish beyond the glass ceiling. First, Niederle, Segal \& Vesterlund (2008) show that women often try to avoid competitive environments. Thus, it is possible that the women who do pursue leadership positions are very similar to men. Second, Branson (2006) presents evidence from court cases against gender discrimination in which women were denied promotion because they acted too "feminine". Therefore, only women who think like men may be promoted by their male colleagues. Third, women in a predominantly male environment may adapt their behavior so that gender differences disappear.

Empirical evidence on gender differences at the executive level is scant partly because so few women are represented in corporate leadership positions. In the US, women held $14.8 \%$ of Fortune 500 board seats in 2007 (Catalyst, 2007). The percentage of female directors in Australia, Canada, Japan, and Europe is estimated to be $8.7 \%, 10.6 \%, 0.4 \%$ and $8 \%$, respectively (Equal Opportunity for Women in the Workplace Agency (EOWA), 2006; European Professional Women's Network (EPWN), 2004). In this paper, we examine gender differences at the executive level using data on board members in Sweden. In 2005, women held $17.34 \%$ of board seats in listed Swedish companies. ${ }^{1}$ Thus, Swedish data lends itself particulary well to a study of gender differences at the executive level.

\footnotetext{
${ }^{1}$ In general, female representation in the boardroom is much higher in Nordic countries than in other countries. The most extreme promotion of gender diversity occurs in Norway, where since January 2008 all listed companies must abide by a $40 \%$ gender quota for female directors or face dissolution.
} 
The main question we ask is: how similar are female executives to male executives? There are many metrics one could use to compare women and men. Since it is impractical to conduct experiments at the executive level, we use survey data. We focus on examining survey measures of directors' values as defined by Schwartz (1992). The Schwartz value survey is among the most advanced that psychologists use, has been replicated in many countries and produces consistent and reliable results. It is particularly useful for our purposes for several reasons. First, values summarize a wide range of potential characteristics. As Schwartz (1992) discusses, values transcend particular situations and actions and are driving forces in life. Schwartz (1992) identifies 10 basic human values that are recognized by all cultures and that leaves out no major value that is meaningful across societies (Schwartz \& Rubel, 2005). Second, researchers have shown that these values predict a variety of actions that the experimental literature argues can explain differences in outcomes across the sexes, for example, voting behavior or altruistic behavior in experiments (see e.g. Andreoni \& Vesterlund, 2001). Third, the European Social Survey uses the Schwartz value survey to study values in the general population in various countries, including Sweden. Thus, we are able to compare values of directors to those in the general population. This enables to examine which gender differences at the population level persist in the boardroom and which do not.

We surveyed the universe of resident directors and CEOs (1,796 individuals) of publicly-traded firms in Sweden in 2005. In addition to the relatively high representation of women among directors, conducting such a survey in Sweden has other advantages. For example, unlike in many other countries, it is straightforward to identify and obtain characteristics of the entire population of directors of publicly-traded corporations. Surveying the population of directors reduces sample selection bias. Having information about characteristics of the population enables us to use Heckman selection techniques to address the possibility of nonresponse bias. Second, gender equality is high in Sweden. This suggests that stereotyping or gender biases should be smaller than in other countries and increases confidence that any gender effects we find are not driven by these biases. 
Finally, Swedish board structure has features that closely resemble those of boards in sole board countries as in the US and UK, but it also shares features with dual board structures as in Germany, for example, the presence of worker representatives on the board. Employees in companies with more than 25 employees have the right to appoint two directors while employees in companies with more than 1000 employees are allowed to appoint up to 3 directors (as long as employee representatives do not constitute a majority on the board). While we focus on the non worker-representatives directors in our analysis, we can use the worker representatives as a robustness check. We take it as re-assuring evidence that our survey measures of values are meaningful since worker representatives differ in reported values from the other directors along expected dimensions.

Our survey instrument consisted of Schwartz's 40 question Portrait Value Questionnaire (PVQ), which we augmented with a question designed to measure risk aversion. We received responses from 628 individuals (a response rate of $36.6 \%$ from directors and $29.7 \%$ percent from CEOs) representing all but $36(12.59 \%)$ of all publicly-traded firms in 2005. The responses indicate that even at the top, women and men are significantly different in terms of values and risk attitudes. Male directors care more about achievement and power than female directors, and less about universalism and benevolence. This is consistent with prior literature that has found that across cultures men consistently attribute more importance to self-enhancement values (achievement and power) (e.g. Schwartz and Rubel, 2005), whereas women emphasize self-transcendence values (universalism and benevolence). However, in contrast to the "typical" gender gaps in the Swedish population and broad patterns documented for other cultures, female directors are less security oriented, less traditional and care more about stimulation than male directors. Surprisingly, but in line with the finding that women in the boardroom care less about security than men, female directors are also slightly more risk-loving than their male colleagues.

To our knowledge, our paper is the first to examine gender gaps at the executive level. We believe the results are interesting for several reasons. First, even though there is plenty of speculation about 
whether increasing gender diversity in management makes a difference, causal evidence is hard to obtain due to endogeneity problems (see, however, Adams and Ferreira, 2008). We document that even at the director level, there are fundamental differences between women and men. This suggests that changes in diversity can have causal effects on corporate outcomes. For example, firms with more female directors might consistently make decisions that are more stakeholder-oriented, because female directors emphasize self-transcendence values more. ${ }^{2}$ On the other hand, contrary to conventional wisdom, increasing gender diversity need not result in more risk-averse decision making.

Second, understanding whether women in leadership positions are different from "typical" women in the population may help reduce statistical discrimination. Anecdotal evidence suggests that firms may be reluctant to appoint women to leadership positions because they believe they are too risk-averse or conservative. Our evidence suggests that women in leadership positions do not satisfy these gender stereotypes. While prospective female candidates for leadership positions are not equivalent to women who already occupy leadership roles, our results are at least suggestive that such candidates may have different attributes than the population average.

Our results are also interesting to understand potential implications of recent affirmative action policies concerning gender quotas at the director level. In Norway, since 2008 all shareholder-owned companies are by law required to have at least $40 \%$ women in the boards. In Spain, the government passed guidelines to encourage companies to increase the share of female directors with the goal of 40\% female representation by 2015 (see Proyecto de Codigo Unificado de Recomendaciones de Buen Gobierno de Sociedades Cotizadas). The larger the gender quota, the more likely it is that women will be chosen as directors who are similar to the population average. As we show, these women may have substantially different attributes than women who obtained their director position in the

\footnotetext{
${ }^{2}$ Adams, Licht and Sagiv (2008) show that directors with higher benevolence/universalism values are more likely to side with stakeholders if their interests conflict with those of shareholders.
} 
competitive market for directors. Understanding these differences may help explain the impact of these gender quotas on corporate outcomes.

The remainder of the article is structured as follows. Section 2 relates our paper to the literature. Section 3 gives some background information on Swedish boards and the data we use. Section 4 presents the main analysis of gender differences in the boardroom. Section 5 highlights the differences between the directors and the comparable Swedish population, and Section 6 concludes.

\section{Relation to the Literature}

This paper lies at the intersection of the gender and management literature, and therefore relates directly to both strands of the literature. As for existing research on gender, our results compare most directly with the experimental literature on gender differences in competition.

Our starting point is the observation that in many countries the share of women in competitive high-ranking positions is low. While discrimination based on gender is one possible explanation for this fact, experimental results by Gneezy, Niederle \& Rustichini (2003), Niederle \& Vesterlund (2007) and Niederle, Segal \& Vesterlund (2008) point to other relevant factors: first of all, women perform less well in competitive environments, even if they are able to perform similarly in non-competitive environments (Gneezy, Niederle \& Rustichini, 2003). ${ }^{3}$ Furthermore, Niederle \& Vesterlund (2007) and Niederle, Segal \& Vesterlund (2008) show that conditional on ability, women choose competitive tournaments much less than men, and therefore shy away from competition. Compared to the payoff-maximizing strategies, too many low ability men enter the tournaments, and too few high ability women.

\footnotetext{
${ }^{3}$ The experiments were conducted with students of engineering in Haifa, Israel. In each group (three men, three women), students had to solve computerized mazes. In the benchmark treatment, payoffs depended solely on the individual's own performance: no gender differences in performance were found. In the competitive treatment, only the winner got a prize. Here, men outperform women. While womens' payoff was not affected, mens' payoffs substantially increased.
} 
These experimental studies suggest that women typically dislike competitive environments. This raises the question about the type of women who aspire to competitive management positions. Are they any different from men? Our study examines this issue and answers yes.

With this result, we contribute to the ongoing debate about the potential impact of gender diversity on organizational outcomes. A large body of literature argues that gender diversity can have a significant impact on organizational outcomes (see, e.g. the survey by Milliken and Martins, 1996). However, relatively few studies examine gender diversity in management, partly because of the low representation of women in management. Furthermore, it is often not clear whether the effect of gender diversity can be attributed to fundamental differences between women and men or to other factors that happen to be correlated with gender diversity. For example, in the context of directors gender diversity could have an impact, not because female directors are different from men, but because the population of female directors happens to differ from the population of male directors in terms of age, tenure or other characteristics that are potentially uncorrelated with gender preferences. By establishing that male and female directors appear to differ systematically in their underlying beliefs, their values, our results suggest that fundamental differences between female and male directors may be driving the effects of gender diversity on boards on organizational outcomes.

Finally, we add to a small but growing strand of literature that analyzes how culture, values and attitudes affect economic outcomes (see Guiso, Sapienza \& Zingales, 2006 for an overview). Previous studies have documented effects of culture on labor force participation and fertility (Fernandez, 2007a; Fernandez, 2007b), economic exchange (Guiso, Sapienza \& Zingales, 2009), or per capita growth of regions (Tabellini, 2008). In the context of corporations, we analyze the role of values and the likely consequences they have on corporate decisions. 


\section{Data}

\subsection{The Survey}

We used MM Partner, a database containing names of board members of all public and private firms in Sweden to identify the set of directors, CEOs and Vice CEOs (the equivalent of Presidents in a US firm) of all publicly-traded firms in Sweden in 2005. In 2005, there were 288 publicly-traded firms listed on the OMX (A\& O list) and the NGM (Nordic Growth Market). Including Vice CEOs, these firms have 468 CEOs and 1,372 resident board members. We surveyed all CEOs and board members.

To increase the response rate, the survey was mailed to the home addresses of each individual. In addition, we used the help of Statistics Sweden to guarantee that the responses were anonymous. Recipients of the survey mailed their responses to Statistics Sweden, which matched the responses to data on personal characteristics on the basis of personal identifying numbers, but then removed all personal identifying information.

The first survey was sent out on July 14, 2006. We followed it up with two reminders. The last survey response was received on November $11,2006 .{ }^{4}$ In total, we received 502 responses $(36.6 \%)$ from board members and 126 responses $(29.7 \%)$ from CEOs. ${ }^{5}$ Most respondents filled out the entire survey. Thus, we have complete surveys for 485 board members and all CEOs. Although the response rate is good compared to other surveys of top management teams, ${ }^{6}$ an obvious concern in this context is that responses may be biased because female directors differ systematically in their tendency to respond. We address this concern by applying Heckman selection models to individual director responses in Section 4.

\footnotetext{
${ }^{4}$ Because the survey respondents mailed their surveys to Statistics Sweden, we were unable to obtain the exact dates of all responses.

${ }^{5} 32$ of the CEO respondents were Vice CEOs, the rest were CEOs.

${ }^{6}$ For example, Simons, Pelled and Smith (1999) report a response rate of $6 \%$.
} 
From MM Partner, we obtain information on director age, tenure on the board and the identities of worker representatives for the entire population of directors and CEOs. From Osiris, we obtain the 2005 Financial Times industry classification for the sample firms. From Statistics Sweden we obtain information on the number of children and the marital status of each director. From the European Social Survey (ESS) we obtain information on values of individuals in the Swedish population, as we describe in more detail in Section 5 .

\subsection{Director Values}

To measure director and CEO values, we used Schwartz's 40 question Portrait Value Questionnaire (PVQ), which we augmented with a question designed to measure risk aversion. To ensure that the Swedish questions reflected the meaning of the English questions, the English survey was first translated into Swedish and then reverse translated into English.

Schwartz (1992) identifies the 10 main value priorities in life, which he describes as:

1. Self-Direction: Independent thought and action; choosing, creating, exploring.

2. Stimulation: Excitement, novelty, and challenge in life.

3. Hedonism: Pleasure and sensuous gratification for oneself.

4. Achievement: Personal success through demonstrating competence according to social standards.

5. Power: Social status and prestige, control or dominance over people and resources.

6. Security: Safety, harmony, and stability of society, or relationships, and of self.

7. Conformity: Restraint of actions, inclinations, and impulses likely to upset or harm others and violate social expectations or norms. 
8. Tradition: Respect, commitment, and acceptance of the customs and ideas that traditional culture or religion provide the self.

9. Benevolence: Preserving and enhancing the welfare of those with whom one is in frequent personal contact (the "in-group").

10. Universalism: Understanding, appreciation, tolerance, and protection for the welfare of all people and for nature.

Generally, the PVQ poses between three to six questions for each value dimension. For instance, to measure power, one question is: "It is important to him to be rich. He wants to have a lot of money and expensive things", for which the respondent has to state how much like this person he/she is (answers ranging from 6, very much like me, to 1, not like me at all). For the complete set of questions that refer to a specific value, see the Appendix.

Individual values are created by taking the average score of the questions that relate to a certain value and subtracting the mean individual score over all 40 questions to correct for differences in individuals' use of the response scale. By correcting for individual differences in "answering priorities", one can cleanly identify individual's relative value priorities. When dealing with values it is common to drop respondents who skipped too many items, who did not tried to discriminate among their values or who responded in ways suggesting deliberate misrepresentation. In our case, most individuals answered all questions. Thus, we did not drop individuals from the data because of missing data. However, we dropped specific values for individuals if more than $30 \%$ of the value items were missing. We also dropped responses for individuals who indicated the same scale for 25 (or more) out of the 40 value questions (3 occurrences).

We measure risk aversion using a standard question in the literature (see e.g. Dohmen, Falk, Hoffmann \& Sunde, 2006). The question we asked was the following: "Imagine you had won SEK 
$1,000,000$ in a lottery. ${ }^{7}$ Almost immediately after you collect, you receive the following offer from a reputable bank: There is a chance to double the money within two years. It is equally possible that you could lose half of the money invested. Which amount of SEK 1,000,000 would you invest?: 1 (0 SEK), 2 (200,000 SEK) , 3 (400,000 SEK), 4 (600,000 SEK) , 5 (800,000 SEK), 6 (1,000,000).” Higher answers to this risk question therefore indicate a higher level of risk-taking.

\subsection{Summary Statistics}

The top part of Table 1 presents summary statistics for the reported values and the risk aversion question for all respondents. For ease of interpretation, we recoded values so that higher numbers denote higher value priorities. Remember that we work with relative value priorities, i.e. the absolute score for a certain value minus the individual's mean response.

Survey respondents generally rank high on benevolence and self-direction values, and low on the value measuring tradition. Stated values are correlated as expected (see Table A1): people who are ambitious (high power and achievement values) are less caring (low benevolence and universalism values), and people who are conservative (high security, conformity and tradition values) need less stimulation and change (low stimulation, self-direction and hedonism values). Concerning risktaking, Swedish directors would choose to invest on average a bit less than $1 / 3$ of the $1,000,000$ SEK in the lottery.

\section{— insert Table 1 about here -}

The lower part of Table 1 reports summary statistics for individual characteristics, split up by respondent and non-respondent. Respondents and non-respondents appear quite similar, except that the share of CEOs and worker-representative directors is slightly lower in the respondent sample. Interestingly, women show no different respondence behavior than men: 17 percent of

\footnotetext{
${ }^{7} 1,000,000$ SEK corresponds roughly to $\$ 120,000$.
} 
the directors are female, and 17 percent of the respondents are female. Differences in respondence behavior between men and women are also statistically insignificant.

\section{Gender Differences in The Boardroom}

\subsection{Gender Gaps in Values and Risk-Attitudes}

To what extent are female directors different from their male counterpart? To get an answer to this answer, we would like to compare male and female directors in their value priorities and risk attitudes. Since we are primarily interested in comparing male and female directors who made it into the boardroom by other means than employment law, we exclude worker-representatives. That leaves us with a sample of 499 directors. Since CEOs are also board members, we include CEOs in our director category, although our results are similar if we exclude them.

If we label the (relative) values by $Y_{x}$, where $x \in\{1, \ldots, 10\}$, and the risk answer by $Y_{11}$ then for each $x \in\{1, \ldots, 11\}$, we estimate a model of the following type:

$$
Y_{x i}=\alpha+\beta \text { Female }_{i}+\varepsilon_{i}
$$

Here Female is a dummy variable taking a value of 1 if the director is female, and 0 otherwise. Since women in the board are on average slightly younger than men (50 years versus 54 years, t-statistic of 7 for differences in means), we also control for age in the regressions. To allow for possible non-linear effects, we perform saturated regressions with dummy variables for all realized values of age. ${ }^{8}$ To correct for possible interdependencies among directors from the same firm, we

\footnotetext{
${ }^{8}$ The estimated gender effects are quite similar if age enters the regressions linearly, or if we use dummies for different age categories; we present alternative specifications in Table 5.
} 
correct the standard errors for group correlation at the firm level and potential heteroskedasticity. If a director sits on more than one board, we assign them to one of their board seats at random before correcting the standard errors.

— insert Table 2 about here -

Table 2 documents that female and male directors differ in most, but not all value dimensions. Female directors care more about benevolence, universalism and stimulation. On the other hand, they care less about power, security, conformity and tradition. Surprisingly, women in the boardroom are also slightly more risk-loving than men. All this evidence suggests that gender differences do not disappear above the class-ceiling.

How robust are these result? We investigate this issue below.

\subsection{Sample Selection}

One major concern with survey data is sample selection bias. While most studies relying on survey data have no means to address this issue, ${ }^{9}$ our information on respondents as well as non-respondents allows us to estimate a Heckman selection correction model. As an additional exogenous variable in the participation equation, we use the number of co-workers who filled out the survey.

The model is estimated with Maximum Likelihood, and standard errors are clustered at the company level, as above. The top part of Table 3 presents the previous OLS results, the bottom part provides the results from the Heckman selection model.

\section{— insert Table 3 about here -}

\footnotetext{
${ }^{9}$ The European Social Survey and the World Value Survey, for example, provide data for respondents only.
} 
As is clear from the table, correcting for sample selection does not alter the estimated gender gaps in value priorities by much. Although selection plays a role (directors with high security, conformity and tradition values are less likely and directors with high self-direction and stimulation values are more likely to be among the respondents), the selection does not seem to be gender specific.

\subsection{Within-Firm Variation}

So far, we compare the values and risk attitudes of male and female directors at the individual level.

However, it could be the case that certain companies' boards are attractive to board members with specific values, and that within a certain company, gender differences disappear. In that case, diversity in the boardroom no longer exists. ${ }^{10}$

To test this for this possibility, we construct a new data set at the directorship, i.e. director-firm level. In this data each director is matched to all of his or her directorships and thus may occur more than once. We end with a sample of 718 observations. Using this sample, we re-run the previous regressions controlling for firm fixed effects.

\section{— insert Table 4 about here -}

The results in Table 4 strongly suggest that even within firms, gender differences persist. As before, female directors appear less power oriented, more benevolent, and rank lower on security, conformity and tradition. They value high stimulation and self-direction and are willing to take higher risks (although the last coefficient is no longer statistically significant). Thus, the gender differences we document do not appear to be driven by corporate culture or omitted firm effects.

\footnotetext{
${ }^{10}$ At the industry level, the share of women is high in industries with traditionally female customers (household products, apparels, food), and low in typically male-dominated areas (cars, telecommunications, technology); see Table A2. Even though it is still possible that within industries, women and men self-select into companies where similar values are shared, knowledge about the industry seems to be important for male or female representation.
} 


\subsection{Controlling for More Observables}

So far we were very parsimonious in the use of controls. The reason is that many individual characteristics except for gender and age may be influenced by an individual's value system and therefore be endogenous. Nevertheless, it is important to ensure that the gender differences we document are not driven by omitted unobservables. Moreover, it is be interesting to see whether there is a correlation between a director's marital status and his/her reported values. Also, to get a sense about the role of age, we now display age dummies for five-year intervals in the regression. The omitted age group consists of directors younger than 40 .

— insert Table 5 about here —

Table 5 shows that older directors care less about achievement and hedonism, but report higher values for tradition. This is plausible and re-assures us that the stated values are indeed meaningful. As for family status, married directors value stimulation less. It is possible that directors who care a lot about stimulation are less likely to get married. Alternatively, marriage might lead directors to care less about stimulation.

It is noticeable that for each value our estimates of the gender dummy are quite similar across specifications. They do not seem to depend much on whether we include more controls, whether we rely on within-firm or cross-sectional variation, or whether or not we correct for sample-selection. Therefore, our estimated gender differences in the boardroom appear quite robust.

\section{$5 \quad$ Directors, Worker Representatives, and Non-Directors}

In Section 4, we document not only that female directors differ from male directors, but also that female directors appear to be different in ways that contradict previous findings concerning gender

gaps. For example, previous value surveys have documented that women are more security and 
tradition oriented, but less stimulation oriented, than men (Schwartz \& Rubel, 2005). A natural question is whether our sample is biased. Even though we survey the entire population of Swedish directors and selection does not seem to drive our results, it is possible that relying on Swedish data matters: the "typical" gender gaps that exists in other countries might not exist at the population level in Sweden, so that our results simply reflect "atypical" patterns of genders gaps in the Swedish population. We investigate these issues further in this Section. First, we investigate whether directors who made it into the boardroom through the competitive labor market differ from directors who achieved their position partially in response to the law, i.e. worker representative directors. Because worker representatives are supposed to represent workers, ex ante we expect them to be more benevolent and universalist than other directors. If this is indeed the case, then this suggests that the directors values are meaningful. Second, we investigate whether gender gaps in the boardroom differ from those for the general Swedish population. While interesting in its own right, we also think that this analysis has important policy implications. Several countries are thinking about increasing the share of women on the boards, either through informal guidelines as in Spain, or by a legal quota as in Norway. Our analysis clarifies that women who get into the boardroom as a result of employment law or a direct gender quota may differ significantly from women who achieved their seats without regulatory measures.

\subsection{Directors Versus Worker-Representative Directors}

In this Section, we analyze the responses of all Swedish board members, including worker representatives. Comparing worker representatives and "regular" directors is interesting for two reasons: First, we would expect worker representatives to be quite different from other directors. Thus, the comparison serves as a robustness check that the director values are meaningful. Second, companies in countries with co-determination (e.g. Sweden, Germany) can increase the share of women in the 
boardroom by appointing more female worker representatives. Our analysis highlights the ways in which female board members who are recruited from within the company's employees and female board members who are recruited in the market for executives may differ.

To be able to compare the two director types, we estimate the following model for each $x$, $(x=1, \ldots, 11)$

$$
Y_{x i}=\alpha+\beta \cdot \text { Female }_{i}+\gamma \cdot \text { Director }_{i}+\delta \cdot \text { Female } \text { Director }_{i}+\varepsilon_{i}
$$

Director measures a "regular" (i.e. non worker representative) director, and the estimated coefficients can be interpreted with the following conditional expectations in mind:

$$
\begin{aligned}
& \mathrm{E}\left[\mathrm{Y}_{x} \mid \text { Female }=0, \text { Director }=0\right]=\alpha \\
& \mathrm{E}\left[\mathrm{Y}_{x} \mid \text { Female }=0, \text { Director }=1\right]=\alpha+\gamma \\
& \mathrm{E}\left[\mathrm{Y}_{x} \mid \text { Female }=1, \text { Director }=0\right]=\alpha+\beta \\
& \mathrm{E}\left[\mathrm{Y}_{x} \mid \text { Female }=1, \text { Director }=1\right]=\alpha+\beta+\gamma+\delta
\end{aligned}
$$

If $\beta \neq 0$, female worker representatives are different from their male counterpart. If $\gamma \neq 0$, male directors differ from male non-directors, and if additionally $\delta=0$, the gender gap among the worker representatives is the same as the gender gap among the "regular" directors. Finally, female directors are different from female worker representatives, if $\gamma+\delta \neq 0$.

The top panel of Table 6 shows the regression results. First, from the estimated $\gamma$, we see that directors are fundamentally different from worker representatives, and in expected ways. Directors care more about achievement and power, and less about benevolence and universalism than worker representatives. ${ }^{11}$ Using Schwartz's terminology, directors rank high on self-enhancement values

\footnotetext{
${ }^{11}$ This finding parallels Gneezy \& Rustichini's (2006) finding that executives are more competitive than teachers: the former choose competitive incentive schemes more frequently than the latter.
} 
and low on self-transcendence values. Directors also differ from worker representatives along their attitudes towards change. They prioritize self direction and stimulation, at the cost of security, conformity and tradition. Female Directors differ from female worker representatives primarily through the effect of being director (apart from the risk attitude question, the interaction terms $\delta$ are insignificant). Therefore, women who acquired their seat in the boardroom through competition are more power and achievement oriented than worker representatives of the same sex. Also, they are less traditional and more open to change. Note also that they are significantly more risk loving. In fact, female directors differ from all the other members in the boardroom by a significantly higher willingness to take risks.

— insert Table 6 about here -

\subsection{Directors Versus Educated Swedes}

So far we have demonstrated that female directors have different values than male directors. Since the European Social Survey asked a representative sample of the Swedish population the same Schwartz value questions, we are able to compare values of directors to those in the broader population. The European Social Survey (ESS) is a biennial multi-country survey. It collects information about people's behavior patterns, attitudes and beliefs, as measured using a 21-item Schwartz value survey, in at least 23 European countries. The first round was fielded in $2002 / 2003$, the second in 2004/2005 and the third in 2006/2007. We use the ESS from 2006/2007. The ESS sampling report for $2006 / 2007$ provides the following information for the 2006/2007 survey in Sweden: ${ }^{12}$

1) Target population: Residents in Sweden older than 15 (regardless of nationality, citizenship, language or legal status).

2) Sampling Frame: Register of the population, which includes all individuals living in Sweden.

\footnotetext{
${ }^{12}$ Using the 2004/2005 ESS survey as a basis for comparison provides similar results.
} 
3) Contact: By telephone, to set up the time for the interview.

4) Sampling design: Single stage (without clustering) probability sample. Fully random sample of individuals (equal probability selection) born before 1 September 1978.

5) Design effects: No stratification, no clustering, equal probabilities

6) Number of selected people: 3000, number of interviewed: 1995.

Because the ESS does not provide information about the people who did not respond, there is no way to correct for sample selection when using ESS data. The basis for our comparison between Swedish directors and non directors are all respondents who gave valid responses to the 21 items of the (short version of the) Schwartz value survey: 1519 respondents from the ESS survey, and 625 respondents from our director survey, respectively. Since the short version of the Schwartz value survey (containing 21 items) is a subset of the long version of the Schwartz value survey (containing 40 items), it is straightforward to match the responses from our director survey to the responses from the ESS survey by restricting the analysis to the 21 common value questions.

To consider the potential effects of gender quotas, it seems most interesting to compare the directors in our sample to the group of non-directors who are of similar age, between 25 and 74 years, and in possession of a university degree. The bottom panel of Table 6 reports results from the same type of analysis as before, except that now the non-directors are the highly educated Swedes, and no longer the worker representatives. Unfortunately, the ESS contains no risk aversion question, so we can only make the comparison with respect to values. As can be seen from the estimated $\beta$, Swedish women care less about power and achievement, but more about benevolence and universalism than Swedish men. Also, women care relatively less about stimulation. Whether these gender gaps prevail at the director level can be seen from the interaction terms. Since the interaction term is insignificant for achievement, power, benevolence and universalism, the same gender gaps that exist in the Swedish non-director population also exist at the director level. In contrast, however, the gender gaps at the director level are significantly different from the Swedish 
non-director comparison group for security, conformity, tradition and stimulation. While women are quite comparable to men along these dimensions in the Swedish population, female directors care relatively less about security, conformity, tradition and more about stimulation than their male colleagues. Therefore, the very specific sample of female directors causes gender gaps at the director level to be "atypical" when it comes to preferences for conservation and change. Our previous concern that this result might have been caused by "atypical" gender gaps in the Swedish population is unconfirmed.

We round up this discussion with a few observations: First among the Swedish population of highly educated people, women and men report different values. Men care more about selfenhancing values (power, achievement), and less about self-transcendence values (benevolence, universalism). The same gender gap is found at the director level. No matter whether we compare male and female worker representatives, or male and female "regular directors", women appear to be more caring about others and less caring about themselves. Even though the gender gaps among directors and non directors are similar, the level of the values are different. Female and male directors are generally more ambitious than non-directors, and less caring than them. However, men more so than women.

However, regular female directors differ from their male colleagues in different ways than Swedish women differ from Swedish men in general. Among the highly educated Swedes, women appear slightly more traditional and security oriented than men, and they care less about stimulation. However, at the director level, exactly the opposite is true. Women are less traditional and less security oriented; they value conformity less than men, but care more about stimulation than their male colleagues. Therefore, the gender gaps that exist among the highly educated Swedes are reversed when we compare regular directors. Due to the fact that female directors are a very selected group of women with a high need for stimulation and a low demand for security, it makes sense that they are also willing to take more risks. As to be expected, that is no longer true if we 
compare worker representative directors: if anything, female worker representatives are more risk averse than male worker representatives.

How do female directors compare with female worker representatives and Swedish women with a university degree? Clearly, the first group distinguishes itself from the latter two by valuing selfenhancement (power, achievement) more and self-transcendence (benevolence, universalism) less. Furthermore, they value stimulation substantially higher, and conservatism lower. Most strikingly, they are substantially more risk loving and less concerned about security. In all aspects, women who have succeeded in the market for executives are different from female workers who get into the boardroom as a result of employment law and from the sample of Swedish women in possession of a university degree.

\section{Discussion}

The initial question we asked was: are women in the boardroom different from men? Our study answers yes. Male directors value achievement and power relatively more, and benevolence and universalism relatively less. Women, on the other hand, care more about stimulation, and less about security, conformity and tradition. While the first set of gender gaps are consistent with the gender gaps in the population of highly educated Swedes, the latter are not. Therefore, women who make it into the board of companies are a very selected sample with a high taste for stimulation, and a low need for security. Thus, it is not necessarily surprising that, compared to their male colleagues, female directors are willing to take higher risks.

Are these results generalizable to other countries? There are two pieces of evidence that suggests that they may be. First, the differences in value priorities between men and women in the general Swedish population are similar to those reported for other countries. This suggests that the Swedish population is not an outlier in terms of gender gaps. Second, Adams and Ferreira (2008) document 
that more gender-diverse boards in the US have more equity-based pay for directors. This is consistent with our finding that female directors are more risk-loving than male directors.

What are some potential implications for corporate policies? ${ }^{13}$ First, we believe our results provide some insight into why gender diversity appear to have an effect on corporate outcomes, as documented, for example, in Adams and Ferreira (2008) and Levi, Li \& Zhang (2008). Our results suggest that male and female directors have different priorities, which may lead gender diverse boards to also behave differently. Second, our results suggest that changing the gender composition of boards may have long-lasting effects. Despite being in the same position as male directors, female directors are not indistinguishable from them in their priorities. Third, having more female directors need not lead to more risk-averse decision-making. Fourth, our results suggest that more gender-diverse boards may embrace stakeholder interests to a greater extent. Adams, Licht and Sagiv (2008) show that power, self-direction and achievement correlate positively, and universalism correlates negatively, with directors' willingness to consider shareholder interests above stakeholder interests. Since female directors care less about power and more about universalism than male directors, it is possible that more gender diverse boards consider stakeholders interests more broadly. Finally, the values of directors are likely to affect ethical decision making. So far, psychological research points to a positive correlation between ethical behavior and self-reported importance of altruistic values (Bond \& Chi, 1997; Fritzsche \& Oz, 2007). Thus, female directors embrace values that precede ethical decisions more strongly than male directors.

\footnotetext{
${ }^{13}$ Since we have responses for all board members for only a few firms, it is not clear that it would be informative to directly correlate our survey responses with measures of corporate outcomes.
} 


\section{Appendix: Questions related to the different values}

\section{Self-Direction:}

1.Thinking up new ideas and being creative is important to him. He likes to do things in his own original way.

2. It is important to him to make his own decisions about what he does. He likes to be free to plan and to choose his activities for himself.

3. He thinks it's important to be interested in things. He likes to be curious and to try to understand all sorts of things.

4. It is important to him to be independent. He likes to rely on himself.

\section{Stimulation:}

1. He thinks it is important to do lots of different things in life. He always looks for new things to try.

2. He likes to take risks. He is always looking for adventures.

3. He likes surprises. It is important to him to have an exciting life.

\section{Hedonism:}

1. He seeks every chance he can to have fun. It is important to him to do things that give him pleasure.

2. Enjoying life's pleasures is important to him. He likes to 'spoil' himself.

3. He really wants to enjoy life. Having a good time is very important to him.

\section{Achievement:}

1. It's very important to him to show his abilities. He wants people to admire what he does.

2. Being very successful is important to him. He likes to impress other people.

3. He thinks it is important to be ambitious. He wants to show how capable he is.

4. Getting ahead in life is important to him. He strives to do better than others.

\section{Power:}

1. It is important to him to be rich. He wants to have a lot of money and expensive things.

2. It is important to him to be in charge and tell others what to do. He wants people to do what he says.

3. He always wants to be the one who makes the decisions. He likes to be the leader.

\section{Security:}

1. It is important to him to live in secure surroundings. He avoids anything that might endanger his safety.

2. It is very important to him that his country be safe. He thinks the state must be on watch against threats from within and without.

3. It is important to him that things be organized and clean. He really does not like things to be a mess.

4. He tries hard to avoid getting sick. Staying healthy is very important to him.

5. Having a stable government is important to him. He is concerned that the social order be protected. 
Conformity:

1. He believes that people should do what they're told. He thinks people should follow rules at all times, even when no-one is watching.

2. It is important to him always to behave properly. He wants to avoid doing anything people would say is wrong.

3. He believes he should always show respect to his parents and to older people. It is important to him to be obedient.

4. It is important to him to be polite to other people all the time. He tries never to disturb or irritate others.

\section{Tradition:}

1. He thinks it's important not to ask for more than what you have. He believes that people should be satisfied with what they have.

2. Religious belief is important to him. He tries hard to do what his religion requires.

3. He thinks it is best to do things in traditional ways. It is important to him to keep up the customs he has learned.

4. It is important to him to be humble and modest. He tries not to draw attention to himself.

Benevolence:

1. It's very important to him to help the people around him. He wants to care for their well-being.

2. It is important to him to be loyal to his friends. He wants to devote himself to people close to him.

3. It is important to him to respond to the needs of others. He tries to support those he knows.

4. Forgiving people who have hurt him is important to him. He tries to see what is good in them and not to hold a grudge.

\section{Universalism:}

1. He thinks it is important that every person in the world be treated equally. He believes everyone should have equal opportunities in life.

2. It is important to him to listen to people who are different from him. Even when he disagrees with them, he still wants to understand them.

3. He strongly believes that people should care for nature. Looking after the environment is important to him.

4. He believes all the worlds' people should live in harmony. Promoting peace among all groups in the world is important to him.

5. He wants everyone to be treated justly, even people he doesn't know. It is important to him to protect the weak in society.

6. It is important to him to adapt to nature and to fit into it. He believes that people should not change nature. 


\section{References}

[1] Adams, Renée \& Ferreira, Daniel (2008), "Women in the Boardroom and Their Impact on Governance and Performance." Forthcoming: Journal of Financial Economics.

[2] Adams, Renée, Licht, Amir \& Sagiv, Lilach (2008), "Shareholderism: Board Members' Values and the Shareholder-Stakeholder Dilemma." European Corporate Governance Institute Working Paper.

[3] Andreoni, James \& Vesterlund, Lise (2001), "Which is the fair sex? Gender Differences in Alstruism." Quarterly Journal of Economics, 116: 293-312.

[4] Bond, Michael H. \& Chi, Vinnie M.-Y. (1999), "Values and Moral Behavior in Mainland China." Psychologia, 40: 251-264.

[5] Branson, Douglas M., 2006, No Seat at the Table: How Corporate Governance Keeps Women Out of America's Boardrooms, NYU Press, New York.

[6] Croson, Rachel \& Gneezy, Uri (2004), "Gender Differences in Preferences," Working paper, Wharton School of Management.

[7] Dollar, David, Fisman, Ray \& Gatti, Roberta (2001), "Are Women Really the 'Fairer' Sex? Corruption and Women in Goverment," Journal of Economic Behavior and Organization, 46: 423-429.

[8] Dohman, Thomas, Falk, Armin, Huffman, David \& Sunde, Uwe (2006), "The Intergenerational Transmission of Risk and Trust Attitudes," IZA DP. 2380.

[9] Eckel, Catherine C. \& Grossmann, Philip J. (2008), "Men, Women and Risk Aversion: Experimental Evidence, in: Plott, C., \& V. Smith, Handbook of Experimental Results. 
[10] Fernandez, Raquel (2007a), "Culture and Economics." Forthcoming: New Palgrave Dictionary of Economics, 2nd edition, edited by Steven N. Durlauf and Lawrence E. Blume. Palgrave Macmillan.

[11] Fernandez, Raquel (2007b), "Culture and Economics." Journal of the European Economic Association, 5(2-3): 305-332.

[12] Fritzsche, David J. \& Oz, Effy (2007), "Personal Values' Influence on the Ethical Dimension of Decision Making." Journal of Business Ethics, 75: 335-343.

[13] Gneezy, Uri, Niederle, Muriel \& Rustichini, Aldo "Performance in Competitive Environments: Gender Differences", Quarterly Journal of Economics, CXVIII, August 2003, $1049-1074$.

[14] Gneezy, Uri \& Rustichini, Aldo (2006), "Executives versus Teachers: Gender, Competition and Self Selection," Mimeo.

[15] Guiso, Luigi, Sapienza, Paola \& Zingales, Luigi (2003), "Cultural Biases in Economic Exchange ", Quarterly Journal of Economics, 124(3): 1095 - 1131.

[16] Guiso, Luigi, Sapienza, Paola \& Zingales, Luigi (2006) "Does Culture Affect Economic Outcomes ", Journal of Economic Perspectives, 20(2): 23 - 48.

[17] Huffington (2003), "Would things be any different if women ran corporate America," www.commondreams.org.

[18] Kirk, Matrice Ellis \& Gwin, Bonnie W. (2009) "A Diverse Corporate Board is More Important than Ever", Corporate Board Member, April 7, http://www.boardmember.com/Article_Details.aspx?id=3420.

[19] Kristof, Nicolas, 2009, "Mistresses of the Universe", The New York Times, February 7, 
http://www.nytimes.com/2009/02/08/opinion/08kristof.html.

[20] Levi, Maurice, Kai Li and Feng Zhang (2008) "Mergers and Acquisitions: The Role of Gender," Working paper, University of British Columbia.

[21] Littrell, Rome (2007), "Proper Use of the Schwartz Value Survey. Draft Users Manual." Downloadable at: www.crossculturalcentre.homestead.com

[22] Marini, Margaret Mooney (1990), "Sex and Gender: What Do We Know?" Sociological Forum, 5, 95-120.

[23] Milliken, Frances and Luis L. Martins, 1996, "Searching for Common Threads: Understanding the Multiple Effects of Diversity in Organizational Groups," Academy of Management Review, 21(2), 402-433.

[24] Morris, Nigel (2009), "Harriet Harman: 'If only it had been Lehman Sisters", The Independent, August 4, http://www.independent.co.uk/news/uk/home-news/harrietharman-if-only-it-had-been-lehman-sisters-1766932.html.

[25] Niederle, Muriel, \& Vesterlund, Lise (2007), "Do Women Shy Away from Competition? Do Men Compete Too Much?," Quarterly Journal of Economics, 122(3), 1067-1101.

[26] Niederle, Muriel, Segal, Carmit \& Vesterlund, Lise (2008), "How Costly is Diversity? Affirmative Action in the Light of Gender Differences in Competitiveness," Working Paper.

[27] Sapienza, Paola, Zingales, Luigi \& Maestripieri, Dario (2009), "Gender Differences in financial risk aversion and career choices are affected by testosterone,"Proceedings of the National Academy of Sciences of the United States, forthcoming.

[28] Schwartz, Shalom H. (1992), "Universals in the content and structure of values: Theo- 
retical advances and empirical tests in 20 countries. In M.P. Zana (Ed.), Advances in experimental social psychology ,"New York, Academic Press.

[29] Schwartz, Shalom H. (2006), "Basic Human Values: An Overview,"Mimeo.

[30] Schwartz, Shalom H. \& Rubel, Tammy (2005), "Sex Differences in Value Priorities: Cross-Cultural and Multimethod Studies," Journal of Personality and Social Psychology, 89(6), 1010-1028.

[31] Simons, Tony, Pelled, Lisa H. \& Smith, Ken A. (1999), "Making a Difference: Diversity, debate and decision comprehensiveness in top management teams," Academy of Management Journal, 42(6), 662-673.

[32] Swedish Code of Corporate Goveranance (2005), available at http://www.bolagsstyrningskollegiet.se/files/docs/Svensk_kod_for_bolagsstyrning_ENG_070913.pdf.

[33] Tabellini, Guido (2008), "Institutions and Culture. Journal of the European Economic Association, 6(2-3), 255-294. 
TABLE 1

Summary Statistics

\begin{tabular}{|c|c|c|c|c|c|}
\hline & Observations & Mean & Std. Dev. & Min & Max \\
\hline \multicolumn{6}{|l|}{ Values (relative) } \\
\hline Achievement & 625 & 0.02 & 0.76 & -2.4 & 2.35 \\
\hline Power & 625 & -0.44 & 0.74 & -3.18 & 1.94 \\
\hline Security & 625 & -0.06 & 0.63 & -2.03 & 1.43 \\
\hline Conformity & 625 & -0.28 & 0.73 & -2.35 & 1.83 \\
\hline Tradition & 625 & -1.25 & 0.59 & -3.10 & 0.47 \\
\hline Benevolence & 625 & 0.56 & 0.59 & -1.55 & 2.25 \\
\hline Universalism & 625 & 0.38 & 0.63 & -1.50 & 2.55 \\
\hline Self-Direction & 625 & 0.91 & 0.63 & -1.25 & 2.85 \\
\hline Stimulation & 625 & -0.13 & 0.86 & -2.65 & 2.55 \\
\hline Hedonism & 625 & -0.04 & 0.88 & -2.65 & 2.38 \\
\hline \multicolumn{6}{|l|}{ Measure Risk-Aversion } \\
\hline Investment: $1(0 \%)$ to $6(100 \%)$ & 617 & 2.63 & 1.42 & 1 & 6 \\
\hline \multicolumn{6}{|c|}{ Individual Characteristics (respondents) } \\
\hline Female Dummy & 628 & 0.17 & 0.37 & 0 & 1 \\
\hline Age & 628 & 54.28 & 9.15 & 25 & 74 \\
\hline Marital Status Dummy & 628 & 0.79 & 0.41 & 0 & 1 \\
\hline Nr. Kids & 628 & 2.18 & 1.16 & 0 & 7 \\
\hline CEO-Dummy & 628 & 0.20 & 0.40 & 0 & 1 \\
\hline Worker-Representative-Dummy & 628 & 0.20 & 0.40 & 0 & 1 \\
\hline \multicolumn{6}{|c|}{ Individual Characteristics (all directors) } \\
\hline Female Dummy & 1796 & 0.17 & 0.38 & 0 & 1 \\
\hline Age & 1796 & 53.07 & 9.20 & 25 & 81 \\
\hline Marital Status Dummy & 1796 & 0.76 & 0.42 & 0 & 1 \\
\hline Nr. Kids & 1796 & 2.12 & 1.14 & 0 & 7 \\
\hline CEO-Dummy & 1796 & 0.24 & 0.42 & 0 & 1 \\
\hline Worker-Representative-Dummy & 1796 & 0.23 & 0.42 & 0 & 1 \\
\hline
\end{tabular}

Notes: The data are from the Swedish director sample. The values are for the survey respondents. The raw value scores range between 1 and 6 , with higher numbers reflecting a higher importance of the respective value dimension. Relative values are centered around the individual's mean response and reflect a respondant's relative value priorities in life. The risk measure is the individuals' answer to how much of 1,000,000 SEK they would invest in a fair lottery (with equal chances of winning the double or loosing half): 0 (1), 20,000 (2), 40,000 (3), 60,000 (4), $80,000(5), 1,000,000(6)$. The first set of individual characteristics is for the survey respondents, the second set for the population of surveyed directors. Marital Status is a dummy variable taking a value of 1 if married, and 0 otherwise. Nr. Kids is the number of children. 
TABLE 2

Values and risk attitudes of male and female directors

\begin{tabular}{|c|c|c|c|c|c|c|}
\hline & Achievement & Power & Security & Conformity & Tradition & Benevolence \\
\hline Female Director & $\begin{array}{l}-0.042 \\
(0.103)\end{array}$ & $\begin{array}{c}-0.323 \\
(0.097)^{\star \star \star}\end{array}$ & $\begin{array}{c}-0.183 \\
(0.090)^{\star \star}\end{array}$ & $\begin{array}{c}-0.346 \\
(0.099)^{\star \star \star}\end{array}$ & $\begin{array}{c}-0.207 \\
(0.076)^{\star \star \star}\end{array}$ & $\begin{array}{c}0.31 \\
(0.079)^{\star \star \star}\end{array}$ \\
\hline Constant & $\begin{array}{c}0.287 \\
(0.065)^{\star \star \star}\end{array}$ & $\begin{array}{c}0.162 \\
(0.219)\end{array}$ & $\begin{array}{c}0.862 \\
(0.343)^{\star *}\end{array}$ & $\begin{array}{c}0.037 \\
(0.306)\end{array}$ & $\begin{array}{c}-1.838 \\
(0.028)^{\star \star \star}\end{array}$ & $\begin{array}{l}0.037 \\
(0.25)\end{array}$ \\
\hline $\begin{array}{l}\text { Observations } \\
\text { R-squared }\end{array}$ & $\begin{array}{l}499 \\
0.11\end{array}$ & $\begin{array}{l}499 \\
0.14\end{array}$ & $\begin{array}{l}499 \\
0.12\end{array}$ & $\begin{array}{l}499 \\
0.11\end{array}$ & $\begin{array}{l}499 \\
0.1\end{array}$ & $\begin{array}{l}499 \\
0.12\end{array}$ \\
\hline & Universalism & Self-Direction & Stimulation & Hedonism & & Risk \\
\hline Female Director & $\begin{array}{c}0.298 \\
(0.080)^{\star \star \star}\end{array}$ & $\begin{array}{c}0.093 \\
(0.086)\end{array}$ & $\begin{array}{c}0.257 \\
(0.103)^{\star \star}\end{array}$ & $\begin{array}{c}0.036 \\
(0.114)\end{array}$ & & $\begin{array}{c}0.296 \\
(0.178)^{\star}\end{array}$ \\
\hline Constant & $\begin{array}{c}-0.338 \\
(0.028)^{\star \star \star}\end{array}$ & $\begin{array}{c}0.537 \\
(0.065)^{\star \star \star}\end{array}$ & $\begin{array}{l}-0.171 \\
(0.522)\end{array}$ & $\begin{array}{c}0.496 \\
(0.275)^{\star}\end{array}$ & & $\begin{array}{c}2.5 \\
(0.371)^{\star \star \star}\end{array}$ \\
\hline $\begin{array}{l}\text { Observations } \\
\text { R-squared }\end{array}$ & $\begin{array}{l}499 \\
0.12\end{array}$ & $\begin{array}{l}499 \\
0.08\end{array}$ & $\begin{array}{l}499 \\
0.11\end{array}$ & $\begin{array}{l}499 \\
0.12\end{array}$ & & $\begin{array}{l}491 \\
0.07\end{array}$ \\
\hline
\end{tabular}


TABLE 3

Gender Gap in Values, Directors (OLS versus Heckman)

\begin{tabular}{|c|c|c|c|c|c|c|c|c|c|c|c|c|}
\hline & & Achiev. & Power & Security & Conformity & Tradition & Benev. & Univers. & Self-Direction & Stimulation & Hedonism & Risk \\
\hline Female Exec. & & $\begin{array}{l}-0.042 \\
(0.103)\end{array}$ & $\begin{array}{c}-0.323 \\
(0.097)^{\star * *}\end{array}$ & $\begin{array}{c}-0.183 \\
(0.090)^{\star *}\end{array}$ & $\begin{array}{c}-0.346 \\
(0.099)^{\star * *}\end{array}$ & $\begin{array}{c}-0.207 \\
(0.076)^{\star * *}\end{array}$ & $\begin{array}{c}0.31 \\
(0.079)^{\star * *}\end{array}$ & $\begin{array}{c}0.298 \\
(0.080)^{\star * *}\end{array}$ & $\begin{array}{l}0.093 \\
(0.086)\end{array}$ & $\begin{array}{c}0.257 \\
(0.103)^{\star *}\end{array}$ & $\begin{array}{l}0.036 \\
(0.114)\end{array}$ & $\begin{array}{c}0.296 \\
(0.178)^{*}\end{array}$ \\
\hline \multirow[t]{2}{*}{$\begin{array}{l}\text { Observations } \\
\text { R Squared }\end{array}$} & & $\begin{array}{l}499 \\
0.11\end{array}$ & $\begin{array}{l}499 \\
0.14\end{array}$ & $\begin{array}{l}499 \\
0.12\end{array}$ & $\begin{array}{l}499 \\
0.11\end{array}$ & $\begin{array}{c}499 \\
0.1\end{array}$ & $\begin{array}{l}499 \\
0.12\end{array}$ & $\begin{array}{l}499 \\
0.12\end{array}$ & $\begin{array}{l}499 \\
0.08\end{array}$ & $\begin{array}{l}499 \\
0.11\end{array}$ & $\begin{array}{l}499 \\
0.12\end{array}$ & $\begin{array}{l}491 \\
0.07\end{array}$ \\
\hline & Part. Equ. & Achiev. & Power & Security & Conformity & Tradition & Benev. & Univers. & Self-Direction & Stimulation & Hedonism & Risk \\
\hline $\begin{array}{l}\text { Female Exec. } \\
\text { Number-Resp. }\end{array}$ & $\begin{array}{c}-0.095 \\
(0.102) \\
0.212 \\
(0.045)^{\star * *}\end{array}$ & $\begin{array}{l}-0.041 \\
(0.099)\end{array}$ & $\begin{array}{c}-0.323 \\
(0.093)^{\star \star \star}\end{array}$ & $\begin{array}{c}-0.183 \\
(0.090)^{\star *}\end{array}$ & $\begin{array}{c}-0.349 \\
(0.099)^{\star \star \star}\end{array}$ & $\begin{array}{c}-0.21 \\
(0.075)^{\star * \star}\end{array}$ & $\begin{array}{c}0.31 \\
(0.076)^{\star \star *}\end{array}$ & $\begin{array}{c}0.297 \\
(0.077)^{\star \star \star}\end{array}$ & $\begin{array}{c}0.094 \\
(0.088)\end{array}$ & $\begin{array}{c}0.259 \\
(0.101)^{\star *}\end{array}$ & $\begin{array}{l}0.036 \\
(0.109)\end{array}$ & $\begin{array}{c}0.294 \\
(0.170)^{\star}\end{array}$ \\
\hline$\overline{\rho \text { (Rho) }}$ & & 0.202 & -0.162 & -0.485 & -0.417 & -0.447 & 0.13 & -0.168 & 0.615 & 0.426 & 0.124 & -0.058 \\
\hline S.E. of $\rho$ & & 0.169 & 0.257 & 0.222 & 0.193 & 0.219 & 0.230 & 0.265 & 0.128 & 0.169 & 0.196 & 0.164 \\
\hline$\lambda($ Lambda $)$ & & 0.141 & -0.108 & -0.31 & -0.301 & -0.262 & 0.073 & -0.096 & 0.414 & 0.366 & 0.104 & -0.083 \\
\hline S.E. of $\lambda$ & & 0.121 & 0.175 & 0.168 & 0.156 & 0.147 & 0.13 & 0.154 & 0.116 & 0.165 & 0.167 & 0.234 \\
\hline Log-Pseudolikelihood & & -1336.88 & -1319.18 & -1259.22 & -1330.5 & -1222.38 & -1230.56 & -1240.198 & -1254.804 & -1416.529 & -1436.247 & -1677.63 \\
\hline Observations & 1378 & 1378 & 1378 & 1378 & 1378 & 1378 & 1378 & 1378 & 1378 & 1378 & 1378 & 1370 \\
\hline $\begin{array}{l}\mathrm{p} \text {-Value for Wald-Test of } \\
\text { independent equations }\end{array}$ & & 0.245 & 0.535 & 0.068 & 0.057 & 0.079 & 0.576 & 0.533 & 0.0005 & 0.028 & 0.532 & 0.722 \\
\hline
\end{tabular}

Notes: The sample consists of all non worker-representative directors. Dependent variables are the centered value dimensions and the risk attitude. Female Executive is a Dummy Variable taking a value of 1 , if female, and 0 otherwise. Age dummies are used as control variables. Number Respondents is the number of directors per company that filled out the survey. Standard errors are clustered at the company level. ${ }^{* *}$ denote significance at the $1 \%$ level, ${ }^{* *}$ significance at the $5 \%$ level, and * significance at the $10 \%$ level. 
TABLE 4

Values and risk attitudes: Within-Firm-Variation

\begin{tabular}{|c|c|c|c|c|c|c|}
\hline & Achievement & Power & Security & Conformity & Tradition & Benevolence \\
\hline Female Director & $\begin{array}{l}-0.039 \\
(0.108)\end{array}$ & $\begin{array}{c}-0.235 \\
(0.110)^{\star \star}\end{array}$ & $\begin{array}{c}-0.186 \\
(0.091)^{\star \star}\end{array}$ & $\begin{array}{c}-0.394 \\
(0.096)^{\star \star \star}\end{array}$ & $\begin{array}{c}-0.205 \\
(0.083)^{\star \star}\end{array}$ & $\begin{array}{c}0.245 \\
(0.094)^{\star \star \star}\end{array}$ \\
\hline Firm-Fixed Effects & Yes & Yes & Yes & Yes & Yes & Yes \\
\hline Observations & 718 & 718 & 718 & 718 & 718 & 718 \\
\hline R-squared & 0.51 & 0.52 & 0.52 & 0.52 & 0.47 & 0.49 \\
\hline & Universalism & Self-Direction & Stimulation & Hedonism & & Risk \\
\hline Female Director & $\begin{array}{c}0.227 \\
(0.089)^{\star \star}\end{array}$ & $\begin{array}{c}0.23 \\
(0.092)^{\star \star}\end{array}$ & $\begin{array}{c}0.376 \\
(0.113)^{\star \star \star}\end{array}$ & $\begin{array}{l}-0.063 \\
(0.138)\end{array}$ & & $\begin{array}{c}0.287 \\
(0.217)\end{array}$ \\
\hline Firm-Fixed Effects & Yes & Yes & Yes & Yes & & Yes \\
\hline Observations & 718 & 718 & 718 & 718 & & 707 \\
\hline R-squared & 0.48 & 0.48 & 0.47 & 0.5 & & 0.43 \\
\hline
\end{tabular}


TABLE 5

Gender Gaps at the Director level: Full set of controls (1)

\begin{tabular}{|c|c|c|c|c|c|c|}
\hline & Achievement & Power & Security & Conformity & Tradition & Benevolence \\
\hline Female Director & $\begin{array}{l}-0.015 \\
(0.108)\end{array}$ & $\begin{array}{c}-0.322 \\
(0.100)^{\star \star \star}\end{array}$ & $\begin{array}{c}-0.22 \\
(0.092)^{\star \star}\end{array}$ & $\begin{array}{c}-0.362 \\
(0.098)^{\star \star \star}\end{array}$ & $\begin{array}{c}-0.212 \\
(0.077)^{\star \star \star}\end{array}$ & $\begin{array}{c}0.326 \\
(0.081)^{\star \star \star}\end{array}$ \\
\hline Age 41-45 & $\begin{array}{l}-0.063 \\
(0.211)\end{array}$ & $\begin{array}{l}0.018 \\
(0.18)\end{array}$ & $\begin{array}{c}-0.011 \\
(0.169)\end{array}$ & $\begin{array}{c}0.091 \\
(0.187)\end{array}$ & $\begin{array}{c}0.221 \\
(0.141)\end{array}$ & $\begin{array}{c}-0.09 \\
(0.146)\end{array}$ \\
\hline Age 46-50 & $\begin{array}{l}-0.204 \\
(0.195)\end{array}$ & $\begin{array}{l}-0.037 \\
(0.186)\end{array}$ & $\begin{array}{c}0.038 \\
(0.158)\end{array}$ & $\begin{array}{l}-0.136 \\
(0.167)\end{array}$ & $\begin{array}{c}0.377 \\
(0.141)^{\star \star \star}\end{array}$ & $\begin{array}{c}0.068 \\
(0.137)\end{array}$ \\
\hline Age 51-55 & $\begin{array}{l}-0.284 \\
(0.197)\end{array}$ & $\begin{array}{c}0.02 \\
(0.178)\end{array}$ & $\begin{array}{c}-0.1 \\
(0.157)\end{array}$ & $\begin{array}{l}-0.092 \\
(0.162)\end{array}$ & $\begin{array}{c}0.268 \\
(0.139)^{\star}\end{array}$ & $\begin{array}{c}0.039 \\
(0.138)\end{array}$ \\
\hline Age 56-60 & $\begin{array}{c}-0.191 \\
(0.195)\end{array}$ & $\begin{array}{l}-0.069 \\
(0.181)\end{array}$ & $\begin{array}{c}0.008 \\
(0.165)\end{array}$ & $\begin{array}{l}-0.041 \\
(0.164)\end{array}$ & $\begin{array}{c}0.341 \\
(0.141)^{\star \star}\end{array}$ & $\begin{array}{c}0.008 \\
(0.144)\end{array}$ \\
\hline Age 61-65 & $\begin{array}{c}-0.311 \\
(0.187)^{\star}\end{array}$ & $\begin{array}{c}0.007 \\
(0.174)\end{array}$ & $\begin{array}{c}0.133 \\
(0.152)\end{array}$ & $\begin{array}{c}0.054 \\
(0.163)\end{array}$ & $\begin{array}{c}0.41 \\
(0.137)^{\star \star \star}\end{array}$ & $\begin{array}{c}0.031 \\
(0.127)\end{array}$ \\
\hline Age 66-70 & $\begin{array}{c}-0.236 \\
(0.214)\end{array}$ & $\begin{array}{l}-0.037 \\
(0.187)\end{array}$ & $\begin{array}{c}0.205 \\
(0.178)\end{array}$ & $\begin{array}{c}0.126 \\
(0.176)\end{array}$ & $\begin{array}{c}0.328 \\
(0.155)^{\star \star}\end{array}$ & $\begin{array}{l}-0.044 \\
(0.147)\end{array}$ \\
\hline Age 70 plus & $\begin{array}{l}-0.463 \\
(0.354)\end{array}$ & $\begin{array}{c}-0.02 \\
(0.248)\end{array}$ & $\begin{array}{c}0.013 \\
(0.205)\end{array}$ & $\begin{array}{c}0.404 \\
(0.262)\end{array}$ & $\begin{array}{c}0.427 \\
(0.218)^{\star}\end{array}$ & $\begin{array}{l}0.061 \\
(0.17)\end{array}$ \\
\hline Married & $\begin{array}{l}0.126 \\
(0.08)\end{array}$ & $\begin{array}{c}0.079 \\
(0.095)\end{array}$ & $\begin{array}{c}0.022 \\
(0.068)\end{array}$ & $\begin{array}{c}0.09 \\
(0.086)\end{array}$ & $\begin{array}{c}0.023 \\
(0.061)\end{array}$ & $\begin{array}{l}-0.074 \\
(0.069)\end{array}$ \\
\hline Nr. Kids & $\begin{array}{c}0.006 \\
(0.028)\end{array}$ & $\begin{array}{l}-0.035 \\
(0.032)\end{array}$ & $\begin{array}{l}-0.016 \\
(0.028)\end{array}$ & $\begin{array}{c}-0.035 \\
(0.032)\end{array}$ & $\begin{array}{l}-0.031 \\
(0.024)\end{array}$ & $\begin{array}{c}0.019 \\
(0.027)\end{array}$ \\
\hline Constant & $\begin{array}{c}0.236 \\
(0.187)\end{array}$ & $\begin{array}{l}-0.273 \\
(0.18)\end{array}$ & $\begin{array}{l}-0.098 \\
(0.149)\end{array}$ & $\begin{array}{c}-0.309 \\
(0.160)^{\star}\end{array}$ & $\begin{array}{c}-1.506 \\
(0.126)^{\star \star \star}\end{array}$ & $\begin{array}{c}0.49 \\
(0.125)^{\star \star \star}\end{array}$ \\
\hline Observations & 499 & 499 & 499 & 499 & 499 & 499 \\
\hline R-squared & 0.02 & 0.03 & 0.04 & 0.06 & 0.04 & 0.04 \\
\hline
\end{tabular}

Notes: See Table 2. New controls are a dummy for marital status, and a count variable for the number of kids. Standard errors are clustered at the company level. ${ }^{* \star}$ denote significance at the $1 \%$ level, ${ }^{* *}$ significance at the $5 \%$ level, and ${ }^{*}$ significance at the $10 \%$ level. 
TABLE 5

Gender Gaps at the Director level: Full set of controls (2)

\begin{tabular}{|c|c|c|c|c|c|}
\hline & Universalism & Self-Direction & Stimulation & Hedonism & Risk \\
\hline Female Director & $\begin{array}{c}0.345 \\
(0.086)^{\star \star \star}\end{array}$ & $\begin{array}{l}0.121 \\
(0.09)\end{array}$ & $\begin{array}{c}0.21 \\
(0.101)^{\star \star}\end{array}$ & $\begin{array}{l}-0.018 \\
(0.115)\end{array}$ & $\begin{array}{c}0.313 \\
(0.179)^{\star}\end{array}$ \\
\hline Age 41-45 & $\begin{array}{l}-0.044 \\
(0.16)\end{array}$ & $\begin{array}{c}0.102 \\
(0.178)\end{array}$ & $\begin{array}{c}0.21 \\
(0.192)\end{array}$ & $\begin{array}{c}-0.469 \\
(0.265)^{\star}\end{array}$ & $\begin{array}{c}0.352 \\
(0.377)\end{array}$ \\
\hline Age $46-50$ & $\begin{array}{c}0.045 \\
(0.159)\end{array}$ & $\begin{array}{c}0.099 \\
(0.159)\end{array}$ & $\begin{array}{c}0.009 \\
(0.179)\end{array}$ & $\begin{array}{l}-0.402 \\
(0.25)\end{array}$ & $\begin{array}{c}0.011 \\
(0.367)\end{array}$ \\
\hline Age 51-55 & $\begin{array}{c}0.099 \\
(0.157)\end{array}$ & $\begin{array}{c}0.097 \\
(0.158)\end{array}$ & $\begin{array}{c}0.345 \\
(0.185)^{\star}\end{array}$ & $\begin{array}{c}-0.425 \\
(0.247)^{\star}\end{array}$ & $\begin{array}{c}0.165 \\
(0.365)\end{array}$ \\
\hline Age 56-60 & $\begin{array}{c}0.091 \\
(0.154)\end{array}$ & $\begin{array}{l}0.116 \\
(0.16)\end{array}$ & $\begin{array}{c}0.187 \\
(0.188)\end{array}$ & $\begin{array}{c}-0.619 \\
(0.251)^{\star \star}\end{array}$ & $\begin{array}{l}-0.061 \\
(0.334)\end{array}$ \\
\hline Age 61-65 & $\begin{array}{c}0.18 \\
(0.149)\end{array}$ & $\begin{array}{c}0.042 \\
(0.155)\end{array}$ & $\begin{array}{l}-0.104 \\
(0.176)\end{array}$ & $\begin{array}{c}-0.78 \\
(0.243)^{\star \star \star}\end{array}$ & $\begin{array}{c}0.086 \\
(0.321)\end{array}$ \\
\hline Age 66-70 & $\begin{array}{c}0.042 \\
(0.164)\end{array}$ & $\begin{array}{c}0.027 \\
(0.176)\end{array}$ & $\begin{array}{c}0.06 \\
(0.191)\end{array}$ & $\begin{array}{c}-0.724 \\
(0.276)^{\star \star \star}\end{array}$ & $\begin{array}{c}0.298 \\
(0.365)\end{array}$ \\
\hline Age 70 plus & $\begin{array}{l}-0.184 \\
(0.193)\end{array}$ & $\begin{array}{c}0.244 \\
(0.199)\end{array}$ & $\begin{array}{c}0.257 \\
(0.304)\end{array}$ & $\begin{array}{c}-0.779 \\
(0.274)^{\star \star \star}\end{array}$ & $\begin{array}{l}-0.164 \\
(0.552)\end{array}$ \\
\hline Married & $\begin{array}{c}0.063 \\
(0.064)\end{array}$ & $\begin{array}{l}-0.054 \\
(0.073)\end{array}$ & $\begin{array}{c}-0.228 \\
(0.102)^{\star \star}\end{array}$ & $\begin{array}{l}-0.153 \\
(0.106)\end{array}$ & $\begin{array}{c}0.031 \\
(0.162)\end{array}$ \\
\hline Nr. Kids & $\begin{array}{c}0.023 \\
(0.022)\end{array}$ & $\begin{array}{l}0.039 \\
(0.03)\end{array}$ & $\begin{array}{c}0.018 \\
(0.039)\end{array}$ & $\begin{array}{l}-0.004 \\
(0.037)\end{array}$ & $\begin{array}{c}0.012 \\
(0.061)\end{array}$ \\
\hline Constant & $\begin{array}{c}0.081 \\
(0.145)\end{array}$ & $\begin{array}{c}0.841 \\
(0.131)^{\star \star \star}\end{array}$ & $\begin{array}{l}-0.029 \\
(0.17)\end{array}$ & $\begin{array}{c}0.636 \\
(0.224)^{\star \star \star}\end{array}$ & $\begin{array}{c}2.434 \\
(0.302)^{\star \star \star}\end{array}$ \\
\hline Observations & 499 & 499 & 499 & 499 & 491 \\
\hline R-squared & 0.05 & 0.01 & 0.05 & 0.05 & 0.01 \\
\hline
\end{tabular}


TABLE 6

Directors, Worker Representatives, and Non Directors

Directors versus Worker Representatives

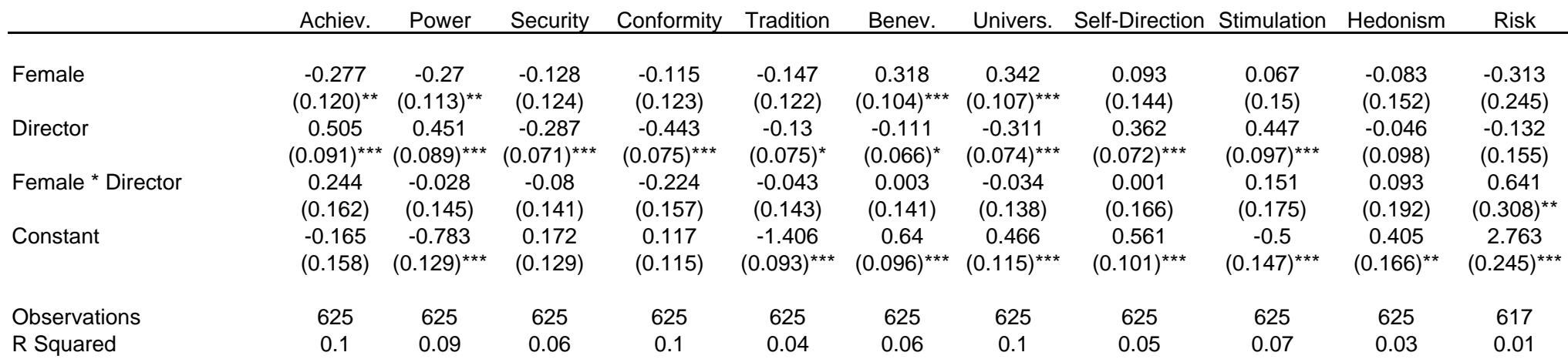

Directors versus Swedish Population

Achiev. Power Security Conformity Tradition Benev. Univers. Self-Direction Stimulation Hedonism

\begin{tabular}{|c|c|c|c|c|c|c|c|c|c|c|}
\hline Female & $\begin{array}{c}-0.209 \\
(0.073)^{\star \star \star}\end{array}$ & $\begin{array}{c}-0.211 \\
(0.068)^{\star \star \star}\end{array}$ & $\begin{array}{c}0.099 \\
(0.077)\end{array}$ & $\begin{array}{l}0.016 \\
(0.08)\end{array}$ & $\begin{array}{c}0.131 \\
(0.076)^{\star}\end{array}$ & $\begin{array}{c}0.262 \\
(0.054)^{\star \star \star}\end{array}$ & $\begin{array}{c}0.158 \\
(0.056)^{\star \star \star}\end{array}$ & $\begin{array}{c}0.006 \\
(0.067)\end{array}$ & $\begin{array}{c}-0.322 \\
(0.082)^{\star \star \star}\end{array}$ & $\begin{array}{l}-0.001 \\
(0.078)\end{array}$ \\
\hline Director & $\begin{array}{c}0.571 \\
(0.073)^{\star \star \star}\end{array}$ & $\begin{array}{c}0.465 \\
(0.068)^{\star \star \star}\end{array}$ & $\begin{array}{c}0.325 \\
(0.072)^{\star \star \star}\end{array}$ & $\begin{array}{c}0.058 \\
(0.075)\end{array}$ & $\begin{array}{c}-0.951 \\
(0.071)^{\star \star \star}\end{array}$ & $\begin{array}{c}-0.186 \\
(0.053)^{\star \star \star}\end{array}$ & $\begin{array}{c}-0.545 \\
(0.057)^{\star \star \star}\end{array}$ & $\begin{array}{c}0.197 \\
(0.065)^{\star \star \star}\end{array}$ & $\begin{array}{c}0.224 \\
(0.081)^{\star \star \star}\end{array}$ & $\begin{array}{c}0.053 \\
(0.082)\end{array}$ \\
\hline Female * Director & $\begin{array}{c}0.153 \\
(0.126)\end{array}$ & $\begin{array}{l}-0.112 \\
(0.117)\end{array}$ & $\begin{array}{c}-0.304 \\
(0.113)^{\star \star \star}\end{array}$ & $\begin{array}{c}-0.343 \\
(0.125)^{\star \star \star}\end{array}$ & $\begin{array}{c}-0.285 \\
(0.108)^{\star \star \star}\end{array}$ & $\begin{array}{c}0.057 \\
(0.096)\end{array}$ & $\begin{array}{c}0.172 \\
(0.097)^{\star}\end{array}$ & $\begin{array}{c}0.084 \\
(0.109)\end{array}$ & $\begin{array}{c}0.53 \\
(0.131)^{\star \star \star}\end{array}$ & $\begin{array}{l}-0.003 \\
(0.139)\end{array}$ \\
\hline Constant & $\begin{array}{c}-0.263 \\
(0.070)^{\star \star \star}\end{array}$ & $\begin{array}{c}-0.592 \\
(0.065)^{\star \star \star}\end{array}$ & $\begin{array}{c}-0.467 \\
(0.070)^{\star \star \star}\end{array}$ & $\begin{array}{c}-0.396 \\
(0.071)^{\star \star \star}\end{array}$ & $\begin{array}{c}-0.341 \\
(0.068)^{\star \star \star}\end{array}$ & $\begin{array}{c}0.644 \\
(0.051)^{\star \star \star}\end{array}$ & $\begin{array}{c}0.574 \\
(0.052)^{\star \star \star}\end{array}$ & $\begin{array}{c}0.581 \\
(0.060)^{\star \star \star}\end{array}$ & $\begin{array}{c}-0.277 \\
(0.074)^{\star \star \star}\end{array}$ & $\begin{array}{c}0.264 \\
(0.072)^{\star \star \star}\end{array}$ \\
\hline Observations & 1007 & 1002 & 1005 & 1002 & 1007 & 1006 & 1008 & 1004 & 1007 & 1006 \\
\hline R Squared & 0.16 & 0.13 & 0.05 & 0.04 & 0.35 & 0.09 & 0.18 & 0.06 & 0.09 & 0.05 \\
\hline
\end{tabular}

Notes: The sample in the top part of the table consists of all directors that responded to the survey - worker representatives and non worker representatives. The sample in the bottom part of the table is a combined sample of the Swedish Director Survey and EES (European Social Survey) survey, third round. All individuals older than 24 and in the possession of a university degree are in the sample. In both parts of the table, the dependent variables are the 10 value dimensions, as identified by Schwartz. All value dimensions are centered around the individuals' mean response and measure their relative value priorities. Female Director is a Dummy Variable taking a value of 1 , if female, and 0 otherwise. Director is a dummy variable taking a value of 1 , if the individual is a non worker representative director. Age dummies are used as control variables. Robust standard errors are reported. ${ }^{* *}$ denote significance at the $1 \%$ level, ${ }^{* *}$ significance at the $5 \%$ level, and * significance at the $10 \%$ level. 
TABLE A1

Correlations between the Values

\begin{tabular}{|c|c|c|c|c|c|c|c|c|c|c|}
\hline & Achievement & Power & Security & Conformity & Tradition & Benevolence & Universalism & Self-Direction & Stimulation & Hedonism \\
\hline Achievement & 1 & & & & & & & & & \\
\hline Power & $\underline{0.4210}$ & 1 & & & & & & & & \\
\hline Security & -0.1621 & -0.1551 & 1 & & & & & & & \\
\hline Conformity & -0.2415 & -0.0560 & 0.3068 & 1 & & & & & & \\
\hline Tradition & -0.4957 & -0.3307 & 0.1694 & 0.2774 & 1 & & & & & \\
\hline Benevolence & -0.3232 & -0.4001 & -0.0828 & -0.1243 & 0.0962 & 1 & & & & \\
\hline Universalism & -0.4292 & $\overline{-0.4879}$ & -0.0790 & -0.1077 & 0.1308 & 0.3070 & 1 & & & \\
\hline Self-Direction & $\overline{0.0660}$ & $\overline{0.0293}$ & -0.3093 & -0.3854 & -0.3584 & -0.0442 & -0.0273 & 1 & & \\
\hline Stimulation & 0.1696 & 0.0563 & $\underline{-0.4938}$ & -0.4365 & $\underline{-0.4076}$ & -0.1470 & -0.1738 & 0.2356 & 1 & \\
\hline Hedonism & 0.0187 & 0.0254 & -0.2816 & -0.3429 & $\overline{-0.1978}$ & -0.0974 & -0.2514 & -0.0334 & 0.2375 & 1 \\
\hline
\end{tabular}

Notes: Bold values are those with correlations higher than 40 percent. 
TABLE A2

Distribution of Female Directors, by Industry

\begin{tabular}{lccc}
\hline \hline Industry & $\begin{array}{c}\text { Gics-Code } \\
\text { (4 digit) }\end{array}$ & $\begin{array}{c}\text { Av. Percentage } \\
\text { Female Directors } \\
\text { per Industry }\end{array}$ & $\begin{array}{c}\text { \# Firms } \\
\text { per } \\
\text { Industry }\end{array}$ \\
\hline Energy & 1010 & 0 & 3 \\
Automobiles & 2510 & 0 & 1 \\
Semiconductor Equipments and Products & 4530 & 0 & 1 \\
Telecommunications Services & 5010 & 0 & 5 \\
Technology Hardware \& Equipment & 4520 & 6.9 & 21 \\
Diversified Financials & 4020 & 8.7 & 24 \\
Transportation & 2030 & 10 & 3 \\
Software \& Services & 4510 & 12.7 & 38 \\
Capital Goods & 2010 & 13.6 & 40 \\
Hotel Restaurants \& Leisure & 2530 & 14.3 & 4 \\
Real Estate & 4040 & 15.8 & 14 \\
Health Care Equipment \& Supplies & 3510 & 16.3 & 15 \\
Materials & 1510 & 16.7 & 16 \\
Pharmaceuticals \& Biotechnology & 3520 & 17.5 & 17 \\
Commercial Services \& Supplies & 2020 & 19.3 & 21 \\
Consumer Durables \& Apparel & 2520 & 20 & 8 \\
Media & 2540 & 20 & 6 \\
Retailing & 2550 & 20.5 & 11 \\
Food Beverage \& Tobacco & 3020 & 28.6 & 4 \\
Insurance & 4030 & 30 & 2 \\
Household \& Personal Products & 3030 & 33.3 & 1 \\
Banks & 4010 & 43.8 & 3 \\
Food \& Staples Retailing & 3010 & 100 & 1 \\
\hline
\end{tabular}

Notes: The table reports the average share of female directors (per industry), and the number of firms per industry. The industry classification is based on the first four digits of the Global Industry Classification System (GICS). 